\title{
The Effect of Trade Openness on Economic Growth: Albanian Case
}

\section{Güngör Turan, Ph.D,}

\author{
Department of Economics, Epoka University, Tirana, Albania \\ gturan@epoka.edu.al
}

Dionis Seni

Master Student at Banking and Finance Department, Epoka University, Tirana, Albania

dseni09@epoka.edu.al

\section{Doi:10.5901/ajis.2014.v3n3p193}

\begin{abstract}
The main purpose of this study is to evaluate and determine the effects of trade liberalization on the economic growth in Albania. The factors included in this project are, foreign direct investment (FDI), exchange rate, and trade openness. Trade openness was computed as the ratio of total of imports and exports to total exports. The methodology comprises the use of the above mentioned macroeconomics indicators which are all gathered by official institution database for an interval time of 10 years measured in quarterly bases'. Secondly a macroeconomic model will be performed in order to understand the impact and relationship of trade openness on economic growth (GDP). Finally based on the result from the statistics of all panel models, it is showed that trade openness and exchange rate has a significantly positive impact on economic growth.
\end{abstract}

Keywords: Trade openness, Economic Growth, Gross Domestic Product, Returns to Scale, Foreign Direct Investment, Exchange Rate

\section{Introduction}

The performance of the Albanian economy in the communist regime was in the worst and unproductive conditions that the country's economy has faced .In this period the the economic model was centralized and closed which mean that we couldn't not export nor import any resources, goods or innovative technology in order to increase the counties production and efficiency in satisfying the needs for goods and services that were needed in other words we were isolated and depending only in our own forces which as time and history has testimonies left our country in the group of the undeveloped and poor countries. This situation start to change when the period of the communist regime was over passed and left behind in 1990 time when Albania changed philosophy in how to lead and direct the country in this period in Albania was establish the democracy and the free open trade economy which lead to a very positive step for the Albanian economy and to the entering to a new stage of evolution for Albanian economy because Albania was now a developing country try to enter to a new phase of improving its welfare and the wellbeing of the Albanian citizens. This short historical introduction was made in order to make more clear why I decided to write this paper that how can be easily understood that is to understand and clarify how trade openness and the advantages that comes from it affect the growth economic GDP and how this factors reflects in the improving of the overall macroeconomic indicators. In the time when open trade economy was implemented in Albania the country was focused on growth enhancing policies including promotion of exports ,in this period a flow of the foreign investment was noticed in the economy whose trend was in a rapid increase year by year fact that was reflected in the increase of the GDP and in an overall improving of the macro situation of the country finally in this article I attempt to explain the effect and the relationship that the trade economic openness has had on the growth economic of Albania this associated with all the other factors that might have played a role in the change of the economic situation of the country as FDI ,Exchange Rate and the Imports and Exports.

\section{Literature Review}

The relationship between trade and productivity has not been theoretically established even though some researchers have found some, if not complete, support for the view that increasing openness has a positive impact on productivity (Elwell, 2005). Albanians economic growth was relatively facing an increasing. The trade openness has played a crucial role in the recovery of the economic situation in Albanian showing that the factors associated with it like fdi exchange rate and import export has faced a big increase which are reflects $d$ in the positive performance of Albanian economy. The data's observed in this article show that trade liberalization had a positive and significant effect on financial and trade 
related reforms and these worked to enhance market efficiency, reduced distortions in price and fostered Albanians competitiveness and access to the global market; thus promoting inflow of capital and expansion of exports. In the 19970 Albania already had a growing fiscal deficit, a current account imbalance and an overvalued exchange rate and all these were supported by project aids and loans at an interest rate of zero or even negative due to bad decisions made by governments to ration credit and foreign exchange instead of increasing the money supply. This resulted in weak market institutions . GDP growth rates in Albania have shown a big increase and improvement fact that is in accordance with the assumption of this paper that the countries that adopted trade liberalization and export-led growth strategies have seen some improvement.

\section{Data and Methodology}

$\mathrm{GDP}=\mathrm{B}_{0}+\mathrm{B}_{1}{ }^{*} \mathrm{FDI}+\mathrm{B}_{2}{ }^{*} \mathrm{RATIO}+\mathrm{B}_{3}$ * EURO

GDP is the dependent variable, which shows the performance of the Albanian economy.

FDI is independent variable that shows the foreign direct investment in Albania.

RATIO is independent variable that is computed as the sum of total import plus total export to total export in order to understand the effect of the trade openness.

Euro is the currency taken in consideration to understand the impact that the changes in the exchange rate over the years have had on the GDP.

Firstly all the variables are tested if they have a normally distribution. A normal distribution means a symmetric distribution and it has a bell shape with a peakness leading to a Skewness of 1 and a tail-thickness leading to a Kurtosis of 3 . If the Skewness is not near to 0 and Kurtosis is not near to 3 the normality distribution is rejected. After doing this on all variables is applied Augmented Dickey Fuller unit root test meaning that all variables are examined if they have a unit root so if they are non stationary. Non stationary means that a series does not fluctuates around a mean value and does not have a tendency of coverage toward mean value. If for $1 \%, 5 \%$ and $10 \%$ level the probability is greater than 0.05 it means that the variable has a unit root (non stationary) so it is first differenced becoming stationary meaning that for $1 \%$, $5 \%$ and $10 \%$ level the probability is lower than 0.05 .

\section{Euro Graph}

EURO

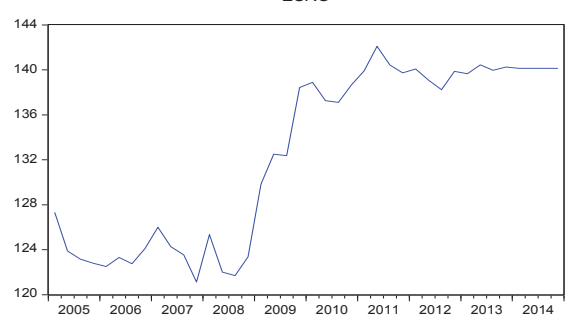

In this graph is shown the line graph of euro in the interval time from (2005-2014). From the graph we can easily notice a small fluctuation of euro from 2005 till 2008 after that as shown in the graph there is a drastic increase of the value of the euro compare to the Albanian currency (ALL).

\section{Ratio (Import-Export) Graph}

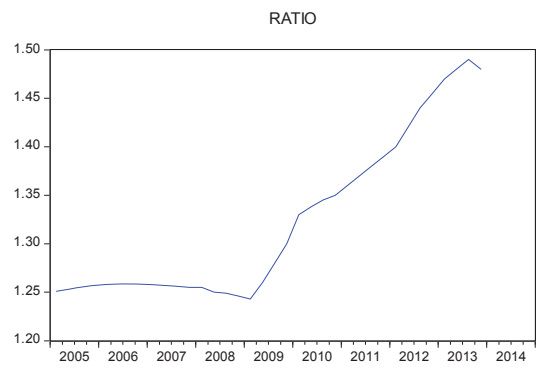


In this figure is shown the graph line of the ratio of trade openness (import-export) in the interval time (2005-2014). From the graph is showed that this ratio has preserved a constant trend till the end of 2008 and after that this ratio is accompanied by a dynamic increase.

\section{GDP \& FDI Graph}

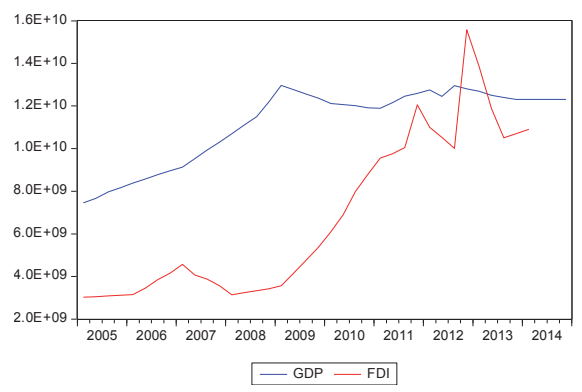

In this graph is shown the relationship of the GDP and FDI from (2005-2014). As shown in the graph from 2005 till 2009 the FDI are in a low level compare to the GDP and are associated with some fluctuations while during the same period the GDP in Albania is in a rapid and significant growth. Despite this fact in the next interval (2009 -2014) the FDI faces a drastic increase till in the year 2012 where it overpasses the increase of the GDP and right after this period it is noticed a decrease of the FDI from the peak that it reached in the first quarter of the 2012. While the GDP during the period 20092014 it shows a slowdown in the rapid increase that was facing and maintains a constant trend of increasing associated with some fluctuations this as a result of the economic crisis.

\section{GDP vs FDI Scatter Graph}

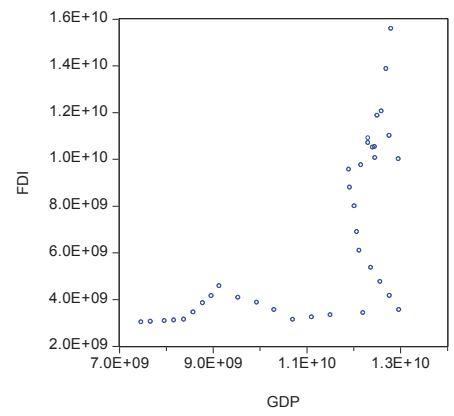

In this figure is showed the scatter graph od GDO and FDI which shows us the connection that this variable have with one another and how this connection has changed through the years.

\section{GDP-Euro Scatter Graph}

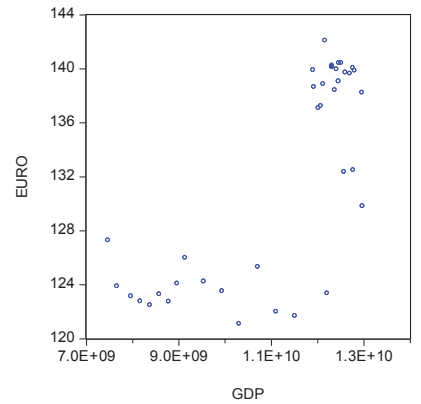


In this figure is showed the scatter graph of GDP and the currency of Euro to demonstrate what relationship this two variables have with one another and how is showed from the graph this relationship is weak in difference with the relationship that the GDP had with FDI but despite this is important to underline the fact that this happens due to the fact that the values of GDP are taken in billion of (ALL) and the Euro values just shows how the exchange rate has changed through the years to explain better how much the euro is converted in the Albanian currency (ALL) through the years and due to this disproportion of values comes this lack of interception.

\section{GDP-Ratio (Import-Export) Scatter Graph}

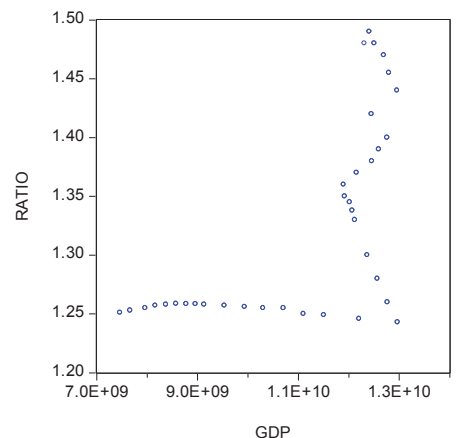

In this figure is showed the scatter graph of GDP and Ratio (import-export) in the same interval of time. From the graph we can observe how the relationship of these two variables has changed through the years.

\section{Histogrm of GDP}

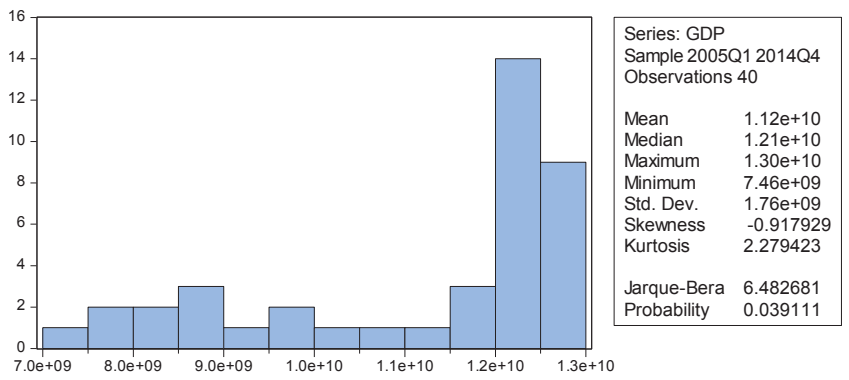

For the GDP the skewness is -0.917929 which is near to 0 and kurtosis is 2.279423 which is near to 3 meaning that the GDP has a normal distribution.

\section{Histogram of Euro}

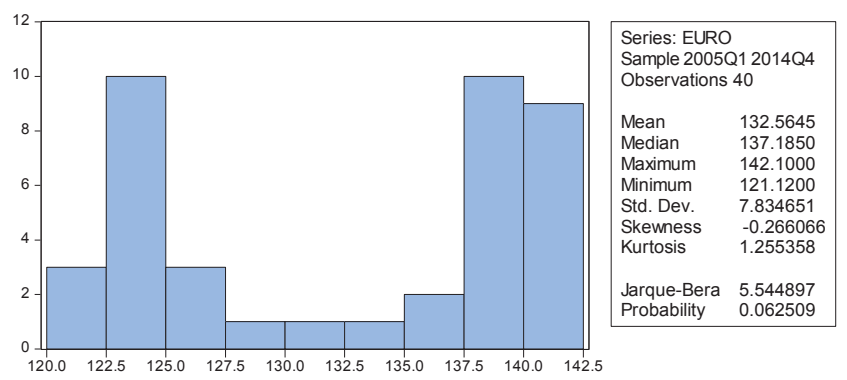


For the exchange rate (Euro) the skewness is -0.266066 which is equal to 0 and kurtosis is 1.255358 which is near to 3 meaning that the euro has a normal distribution.

\section{Histogram of FDI}

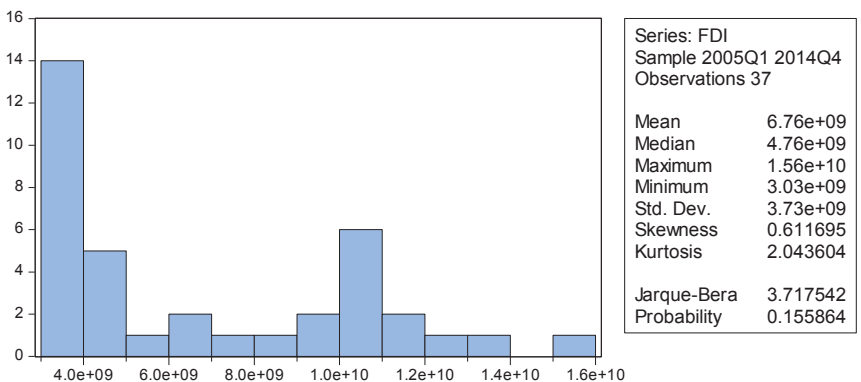

For the FDI the skewness is 0.611695 which is equal to 0 and kurtosis is 2.043604 which is near to 3 meaning that the FDI has a normal distribution.

\section{Histogram of Ratio}

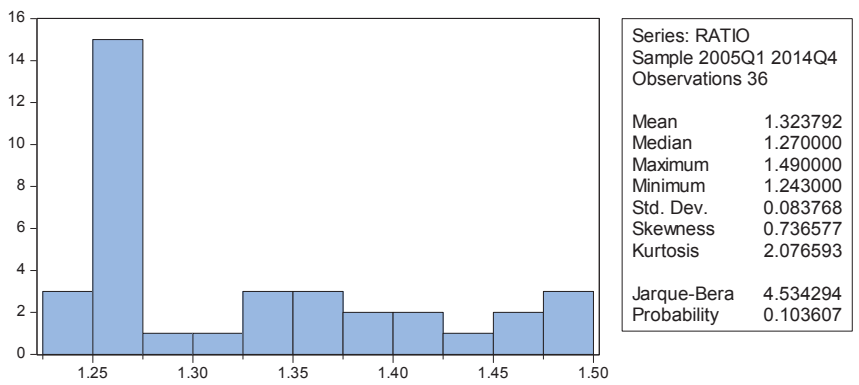

For the ratio the skewness is 0.736577 which is near to 0 and kurtosis is 2.076593 which is near to 3 meaning that this ratio has a normal distribution.

Table.1. Descriptive statistics of all variables.

\begin{tabular}{|l|c|c|c|c|}
\hline & GDP & EURO & FDI & RATIO \\
\hline Mean & $1.11 \mathrm{E}+10$ & 131.7228 & $6.65 \mathrm{E}+09$ & 1.327668 \\
\hline Median & $1.20 \mathrm{E}+10$ & 132.4350 & $4.67 \mathrm{E}+09$ & 1.273716 \\
\hline Maximum & $1.30 \mathrm{E}+10$ & 142.1000 & $1.56 \mathrm{E}+10$ & 1.508259 \\
\hline Minimum & $7.46 \mathrm{E}+09$ & 121.1200 & $3.03 \mathrm{E}+09$ & 1.243716 \\
\hline Std. Dev. & $1.81 \mathrm{E}+09$ & 7.817251 & $3.72 \mathrm{E}+09$ & 0.087318 \\
\hline Skewness & -0.753050 & -0.075457 & 0.690814 & 0.749177 \\
\hline Kurtosis & 1.997789 & 1.207032 & 2.171666 & 2.160742 \\
\hline & & & & \\
\hline Jarque-Bera & 4.909149 & 4.856264 & 3.892549 & 4.424123 \\
\hline Probability & 0.085900 & 0.088201 & 0.142805 & 0.109475 \\
\hline & & & & \\
\hline Sum & $3.99 \mathrm{E}+11$ & 4742.020 & $2.39 \mathrm{E}+11$ & 47.79605 \\
\hline Sum Sq. Dev. & $1.15 \mathrm{E}+20$ & 2138.830 & $4.84 \mathrm{E}+20$ & 0.266856 \\
\hline & & & & \\
\hline & 36 & 36 & 36 & 36 \\
\hline
\end{tabular}


Table.1 shows the group statistic where for each variable is made the same analysis as in the series statistics(mean, median, maximum, minimum, standart Deviation Skewness, kurtosis, Jarqua-Bera, probability, sum, sum Sq. Dev) and again is seen that all variables are normally distributed.

Table 2: Estimated Equation Output

Dependent Variable: GDP

Method: Least Squares

Date: 06/29/14 Time: 15:20

Sample (adjusted): 2005Q1 2013Q4

Included observations: 36 after adjustments

\begin{tabular}{lcccc}
\hline \hline \multicolumn{1}{c}{ Variable } & Coefficient & Std. Error & t-Statistic & Prob. \\
& & & & \\
\hline CURO & 23.57332 & 0.485226 & -0.954714 & 0.3469 \\
FDI & -0.069761 & 0.052005 & 3.297109 & 0.0024 \\
RATIO & 0.062747 & 0.046300 & 0.365901 & 0.7168 \\
& 0.109038 & 0.024869 & -0.465112 & 0.6450 \\
& & & \\
\hline \hline R-squared & 0.581686 & Mean dependent var & 22.36947 \\
Adjusted R-squared & 0.542469 & S.D. dependent var & 0.705002 \\
S.E. of regression & 0.389822 & Akaike info criterion & 44.79719 \\
Sum squared resid & 5.166668 & Schwarz criterion & 44.97314 \\
Log likelihood & -802.3495 & Hannan-Quinn criter. & 44.85860 \\
F-statistic & 14.83251 & Durbin-Watson stat & 0.173457 \\
Prob (F-statistic) & 0.000003 & & \\
& & & \\
\hline \hline
\end{tabular}

\section{The Model}

$\mathrm{GDP}=\mathrm{B}_{0}+\mathrm{B}_{1}{ }^{*} \mathrm{FDI}+\mathrm{B}_{2}{ }^{*} \mathrm{RATIO}+\mathrm{B}_{3}$ *EURO

This equation explains the relation of GDP the dependent variable with the independent variables (FDI, RATIO, and EURO).

As we can see from the results, the effect of FDI over GDP is positive. This means that an increase in GDP with $1 \%$ leads FDI to an increase with 0.06 or $6 \%$. While for $1 \%$ increase in GDP leads Euro to a decrease of $7 \%$ because the increase of the GDP leads to an appreciation of Albanian currency and devaluation of the Euro. Finely $1 \%$ increase in GDP leads in $10 \%$ increase in the trade openness ratio which has actually a great significant and positive impact on the Albanian growth economy.

Table 3. Augmented Dickey-Fuller Unit Root Test on GDP, FDI, Ratio and Euro

\begin{tabular}{l|cccc|}
\multicolumn{1}{c}{ Variables } & 1\% level & $5 \%$ level & $10 \%$ level & Propability \\
\hline GDP & -3.615588 & -2.941145 & -2.609066 & 0.1631 \\
FDI & -3.632900 & -2.948404 & -2.612874 & 0.7990 \\
Ratio & -3.639407 & -2.951125 & -2.614300 & 0.8209 \\
Euro & -3.615588 & -2.941145 & -2.609066 & 0.7753 \\
\hline
\end{tabular}

Table 4. Augmented Dickey-Fuller Unit Root Test on D(GDP), D(FDI), D(Ratio) and D(Euro)

\begin{tabular}{l|cccc}
\multicolumn{1}{c}{ Variables } & 1\% level & $5 \%$ level & $10 \%$ level & Propability \\
\hline D(GDP) & -2.627238 & -1.949856 & -1.611469 & 0.0025 \\
D(FDI) & -2.632688 & -1.950687 & -1.611059 & 0.0002 \\
D(Ratio) & -2.634731 & -1.951000 & -1.610907 & 0.0431 \\
D(Euro) & -2.627238 & -1.949856 & -1.611469 & 0.0001 \\
\hline
\end{tabular}


The augmented Dickey Fuller unit root test is performed on all the variables in order to analyze if they have a unit root or not meaning If the variables are non stationary or stationary in other words if they are integrated in the same order. From the results of Augmented Dickey Fuller Unit Root Test is showed that all the variables have a unit root so they are non stationary because the value of probability is greater than 0.05 but when they are differenced they become stationary because their probabilities are lower than 0.05 .

After converting non stationary variables into stationary, the Johansen co-integration test will be applied in order to observe whether these variables are co-integrated in the long run.

Table 5. Johansen Co-integration Test of GDP

Trend assumption: Linear deterministic trend

Series: GDP EURO FDI RATIO

Lags interval (in first differences): 1 to 2

Unrestricted Cointegration Rank Test (Trace)

\begin{tabular}{lcccc}
\hline \hline $\begin{array}{c}\text { Hypothesized } \\
\text { No. of CE(s) }\end{array}$ & Eigenvalue & $\begin{array}{c}\text { Trace } \\
\text { Statistic }\end{array}$ & $\begin{array}{c}0.05 \\
\text { Critical Value }\end{array}$ & Prob. $^{* *}$ \\
\hline \hline None * & 0.515198 & 56.91005 & 47.85613 & 0.0056 \\
At most 1 * $_{\text {At most 2 }}$ & 0.475003 & 33.01758 & 29.79707 & 0.0206 \\
At most 3 & 0.253043 & 11.75364 & 15.49471 & 0.1691 \\
& 0.062392 & 2.125959 & 3.841466 & 0.1448 \\
\hline \hline
\end{tabular}

Trace test indicates 2 cointegrating eqn(s) at the 0.05 level

* denotes rejection of the hypothesis at the 0.05 level

**MacKinnon-Haug-Michelis (1999) p-values

Unrestricted Cointegration Rank Test (Maximum Eigenvalue)

\begin{tabular}{lcccc}
\hline \hline $\begin{array}{c}\text { Hypothesized } \\
\text { No. of CE(s) }\end{array}$ & Eigenvalue & $\begin{array}{c}\text { Max-Eigen } \\
\text { Statistic }\end{array}$ & $\begin{array}{c}0.05 \\
\text { Critical Value }\end{array}$ & Prob. $^{* *}$ \\
\hline \hline None & 0.515198 & 23.89247 & 27.58434 & 0.1385 \\
At most 1 * & 0.475003 & 21.26394 & 21.13162 & 0.0479 \\
At most 2 & 0.253043 & 9.627680 & 14.26460 & 0.2376 \\
At most 3 & 0.062392 & 2.125959 & 3.841466 & 0.1448 \\
& & & & \\
\hline \hline
\end{tabular}

Max-eigenvalue test indicates no cointegration at the 0.05 level

* denotes rejection of the hypothesis at the 0.05 level

**MacKinnon-Haug-Michelis (1999) p-values

In Table 5, Trace test indicates 2 co-integrating equations at the 0.05 level where the Trace statistic is greater than $5 \%$ critical value while Max-Eigen value test indicates that there is no co-integration at 0.05 level because Max-Eigen statistic is lower than $5 \%$ critical value. In other words GDP and the other three variables: FDI, RATIO, and the EURO are cointegrated to each other but in the long run this co-integration is weak.

\section{Conclusions}

This article has showed that the effect of the trade openness on the economic growth of Albania has a significant and positive impact on the GDP and on the macroeconomic indicators .From the statistical result is showed that exist a strong relationship and that the variables are co integrated with one another even though that in the long run this co integration appear not to be so strong. hats why in order to keep this situation some reforms are needed to be undertaken that are as follow, try to keep a positive balance of net export and try to be an attractive country to the foreign investment and finally to maintain a healthy exchange rate in order to preserve the value of the native currency. 


\section{References}

World Bank

Bank of Albania

Instat.gov.al

Indexmundi

Abdelkader Boundriga, Neila Boulila Taktak and Sana Jellouli (2014) "Does bank supervision impact nonperforming loans: crosscountry determinants using aggregate data?",

Bank of Albania quarterly reports for 2003

Bank of Albania quarterly reports for 2004

Bank of Albania quarterly reports of 2005

Bank of Albania quarterly reports of 2006

Bank of Albania quarterly reports of 2007

Bank of Albania quarterly reports of 2008

Bank of Albania quarterly reports of 2009

Bank of Albania quarterly reports of 2010

Bank of Albania quarterly reports of 2011

Bank of Albania quarterly reports of 2012

Bank of Albania quarterly reports of 2013

Bruna Skarica (2013) "Determinants of nonperforming loans in Central and Eastern European countries", 